\title{
Review
}

\section{Diagnosis of viral gastroenteritis: limits and potential of currently available procedures}

\author{
Francesca Sidoti ${ }^{1,2 \star}$, Massimo Rittà ${ }^{1,2 \star}$, Cristina Costa ${ }^{1,2}$, Rossana Cavallo ${ }^{1,2}$ \\ ${ }^{1}$ Microbiology and Virology Unit, Laboratory of Virology, Azienda Ospedaliero Universitaria Città della Salute e \\ della Scienza di Torino, Turin, Italy \\ ${ }^{2}$ Department of Public Health and Pediatrics, University of Turin, Italy
}

* Both authors equally contributed to this study and share first authorship.

\begin{abstract}
The diagnostic approaches to viral gastroenteritis have evolved substantially over the past decades because of the advances in detection methods, the emergence of new pathogens, and the increase in diarrhea hospitalizations attributed to viruses, especially in young children in non-industrialized countries.

Overall, these factors have lead to a relevant improvement of types and operating characteristics of diagnostic methods (including sensitivity and specificity), as well as turnaround time.

In this review, clinical and laboratory approaches to the diagnosis of viruses causing gastroenteritis are presented; in particular, specimen collection and detection methods are reviewed and discussed, taking into account performance and limitations.
\end{abstract}

Key words: diarrhea; gastroenteritis; virus; diagnosis.

J Infect Dev Ctries 2015; 9(6):551-561. doi:10.3855/jidc.7051

(Received 24 April 2015 - Accepted 16 May 2015)

Copyright $($ ) 2015 Sidoti et al. This is an open-access article distributed under the Creative Commons Attribution License, which permits unrestricted use, distribution, and reproduction in any medium, provided the original work is properly cited.

\section{Introduction}

Acute gastroenteritis (AGE) is a common cause of morbidity and mortality worldwide, with most cases occurring in young children in non-industrialized countries. In recent years, improvements in hygiene, sanitation, and water supply have led to a reduction of the cases of bacterial and parasitic infections, with a parallel increase in diarrhea-related hospitalizations attributed to viruses [1]. AGE is a major cause of illness in the United States, with an estimated 179 million episodes occurring annually [2]. Approximately 1.45 million deaths related to AGE occur worldwide every year [3-5]. AGE is estimated to be responsible for the deaths of 800,000 infants and young children each year $[6,7]$. Noroviruses are the leading cause of single-agent outbreaks $(68 \%$ of cases), followed by Salmonella spp. (13\%), Shigella spp. (4\%), and Shiga toxin-producing Escherichia coli (4\%) [8]. Low-income countries are affected by the most severe outcomes of AGE; more than $25 \%$ of deaths in children younger than five years of age are attributable to acute gastroenteritis in Africa and Southeast Asia $[9,10]$.
Although at least 25 different bacteria and protozoa can cause childhood diarrhea, more than $75 \%$ of cases are caused by viruses; the most frequently detected viral agents of acute gastroenteritis are rotavirus, norovirus, enteric adenovirus, human astrovirus, and sapovirus. The main biological features of viruses associated with acute gastroenteritis in humans are shown in Table 1. Other viruses, such as Aichi virus, parechovirus, and bocavirus have been recently described in patients with diarrhea, but their association with AGE has not yet been established clearly [7,11-15]. Although rotavirus is reported to be the most common pathogen in children worldwide, the role of other enteric viruses is relatively less understood $[1,16]$. Three main types of manifestations are reported: (a) sporadic infantile gastroenteritis (GE) (mainly due to rotaviruses); (b) epidemic GE in adults and children (calicivirus: norovirus and sapovirus); and (c) sporadic GE of adults (calicivirus, rotavirus, astrovirus, adenovirus). Important epidemiological factors include history of contact, travel history (including cruise ships), eating history, and daycare history. Clinical presentation of AGE varies from 
asymptomatic infections to severe diarrhea, vomiting, and dehydration, with an emerging risk of death. Typical presentations of viral AGE include a short prodromal phase, with mild fever and vomiting, followed by one to four days of non-bloody, watery diarrhea. However, the great majority of viral AGE is self-limiting, not leading to precise diagnosis and identification of the viral agent; these aspects limit further understanding of its physiopathologic and epidemiologic characteristics [7,16-19].

This paper is an update review on recent achievements in the field of diagnosis of viral gastroenteritis, and points out the main features of the licensed available assays and their clinical implications.

\section{Descriptions of the agents}

Calicivirus

The Caliciviridae family comprises four genera: Norovirus, Sapovirus, Lagovirus, and Vesivirus; human norovirus and sapovirus are etiological agents of gastroenteritis.

\section{Norovirus}

Norovirus (NoV) is considered the major cause of AGE in both children and adults in community-based gastroenteritis; it is responsible for sporadic cases and several outbreaks in various epidemiological settings, including restaurants, schools, daycare centers, hospitals, nursing homes, and cruise ships. More than $267,000,000$ annual infections have been reported worldwide [16].

The genus Norovirus is divided into six genogroups (G-I to G-VI). Viruses in genogroup I, II, and IV are known to infect humans, with most strains associated with human disease belonging to G-I and G-II. Transmission routes include contaminated food, water, environment, person-to-person contact, air, stool, and vomit of infected person. Waterborne outbreaks are more likely to be caused by G-I NoVs, whereas foodborne outbreaks or person-to-person transmission are mainly related to G-II strains [20,21]. Prolonged infections by norovirus and viral shedding have been observed in immunosuppressed hosts, in whom infections may occur year-round [20,22].

Noroviruses possess highly infectious potential, with a small inoculum (as few as 10-100 virions) required for infection; furthermore, virions are relatively stable in the environment, with reported resistance to freezing, heating to $60^{\circ} \mathrm{C}$, and disinfection with chlorine [16,23,24].

Noroviruses have been found to recognize specific histo-blood group antigens (HBGAs) as receptors for attachment in the gut; all three major HBGA families ( $\mathrm{ABO}$, secretor, and Lewis) are involved in the process of NoV recognition. Rotaviruses and other bacterial pathogens such as Helicobacter pylori, have also been found to recognize HBGAs [25].

\section{Sapovirus}

Sapovirus particles were first detected in human diarrheal stools in 1976 in the United Kingdom [26], and the prototype of human sapovirus was identified during an outbreak in Sapporo, Japan, in 1977 [27]. Sapoviruses cause acute gastroenteritis in humans and animals and are responsible for gastroenteritis in people of all ages in both outbreaks and sporadic cases worldwide [28]. They are the causative agents of AGE in only a minority of cases of sporadic gastroenteritis in children. However, the incidence of sapovirusassociated gastroenteritis in adults is steadily increasing, suggesting a rise in virulence and prevalence $[29,30]$. In general, the severity of sapovirus gastroenteritis is milder than that of norovirus, and mortality is rare. Sapoviruses are associated with more serious clinical complications in susceptible groups (e.g., premature neonates and immunocompromised patients) [22,28,31].

Sapoviruses can be divided into five genogroups (GI-GV), among which GI, GII, GIV, and GV are

Table 1. General characteristics of the main viral agents responsible for gastroenteritis worldwide

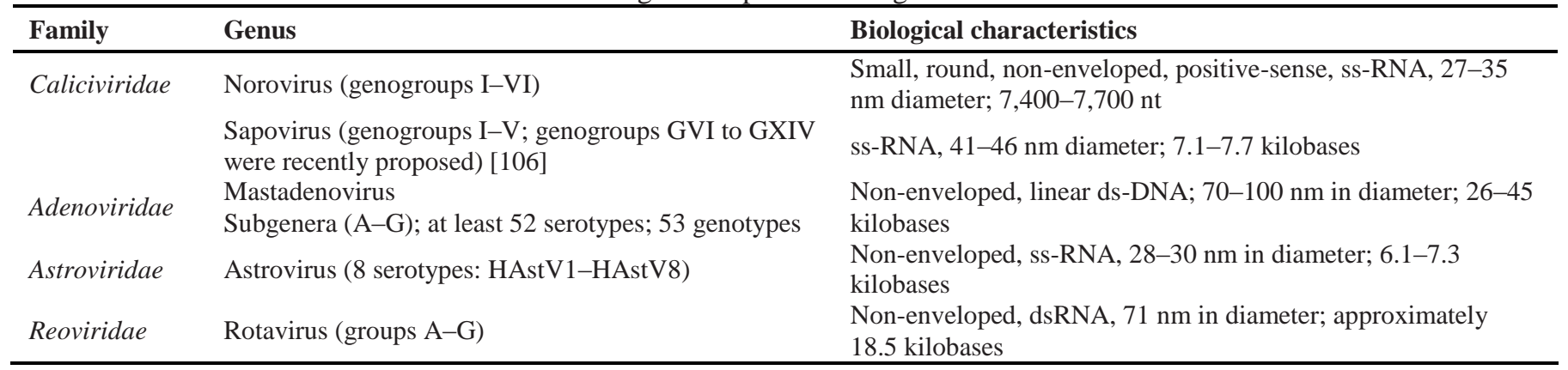


known to infect humans; sapovirus GIII infects porcine species. The infection is more common in young children than in adults, usually occurring by five years of age, especially at daycare centers and institutions [30].

Seroprevalence studies of human sapoviruses demonstrated a gradually increasing seroprevalence rate with age, which reached a high level $(>90 \%)$ in school-age children, and remained high (80\%-100\%) in sera collected from adults [32-35], suggesting that sapovirus infection is common during early childhood. Adults with serum antibodies to antigenically indistinguishable human sapoviruses did not show any clinical symptoms of reinfection [28].

\section{Adenovirus}

Human adenoviruses (ADV) are non-enveloped DNA viruses, belonging to the family Adenoviridae. They are the only DNA viruses among the most common viral pathogens in children, and have been associated with a spectrum of clinical presentations including respiratory, gastrointestinal, ocular, and urinary tract infections [1]. Adenovirus infections are largely asymptomatic, and only one-third of the 52 recognized human serotypes are associated with a specific human disease, including upper and lower respiratory tract manifestations, conjunctivitis, cystitis, and gastroenteritis. Enteric adenoviruses are second only to rotavirus as agents of AGE in infants and young children. Diarrheic manifestations can occur during infection by any type of ADV (especially serotypes $18,31,40,41$, and 52). Diarrhea is usually associated with fever, and can last for up to two weeks. Following the symptomatic phase, all ADV can remain in the gastrointestinal tract and potentially be excreted for prolonged periods of time (extended periods of time for subgenera $\mathrm{C}$ ), being potentially reactivated in conditions of immune deficiency. Latency sites have been recognized in tonsils, lymphocytes, and adenoidal tissues [36,37]. However, specific subgenera (e.g., subgenera A and D) can be associated with large proportions of asymptomatic infections, and $0 \%-20 \%$ of asymptomatic people can shed adenoviruses [38].

\section{Astrovirus}

Human astroviruses (HAstV) are the second-most common cause of gastroenteritis in children, after rotaviruses, with incidence varying from $4.3 \%-8.6 \%$. Early studies indicated that HAstV1 is the most prevalent serotype worldwide, although there are increasing reports of the role of other serotypes in gastroenteritis [1,39,40]. Sporadic, communityacquired, and nosocomial infections have been described [41,42]. HAstVs are usually responsible for mild watery diarrhea lasting no more than three days, and vomiting, fever, anorexia, and abdominal pain are common. Persisting gastroenteritis due to astroviruses has been associated with HAstV3. Astrovirus-related deaths have been reported, though they are extremely rare $[43,44]$.

\section{Rotavirus}

Rotaviruses (RVs) are the leading cause of acute childhood gastroenteritis, with 180,000-450,000 deaths occurring in children under five years of age, especially in developing countries [45,46]. Furthermore, rotavirus infection can sporadically be associated with neurologic manifestations, including benign convulsions, encephalitis, and encephalopathy; data exist on its plausible association with sudden infant death syndrome, necrotizing enterocolitis, intussusception, Kawasaki's disease, and type 1 diabetes [47,48]. Rotaviruses also infect other mammalian and avian species, leading to diarrhea in calves, pigs, sheep, and poultry [49]. Two liveattenuated oral rotavirus vaccines (RotaTeq, Merck; Rotarix, GSK Biologicals) have been licensed, after the discontinuation of the quadrivalent RRV-based human reassortant vaccine Rotashield because of the severe adverse cases of gut intussusceptions. Both vaccines were found to reach protection rates of 70 to $>90 \%$ in developed countries. Interestingly, herd protection was observed in non-vaccinated children, probably related to reduced transmission of rotavirus in the community as a result of vaccination $[48,50]$.

\section{Laboratory diagnosis}

\section{Sample collection}

Collection of an adequate specimen is fundamental for a correct diagnosis and to avoid costs and useless investigations. The specimen must be collected as early as possible in the presence of a suggestive clinical presentation, taking into account the acute phase and the duration of viral shedding. The specimen of choice for the diagnosis of the main viruses causing gastroenteritis is feces. Stool samples should be collected from affected individuals as soon as possible after the onset of acute gastroenteritis (between day 1 and 4 of the illness) because viral shedding is highest in the acute phase of the illness. Therefore, liquid diarrhea stool represents the more suitable sample for the detection of gastrointestinal viruses, particularly diarrheal stools defined as types 5 
to 7 on the Bristol Stool Chart. Alternatively, a rectal swab can also be used if feces are not available. The specimen should be stored at $4^{\circ} \mathrm{C}$ until tested, and at $70^{\circ} \mathrm{C}$ for several months in suitable containers, though it should, ideally, be sent to the laboratory as soon as possible. It is good practice to contact the laboratory for information about specimen collection (time and temperature), conservation and to send information and to concur them, as well as to report complete information regarding the patient, such as age, underlying pathologies and co-morbidities, life habits, clinical suspect, therapies, and previous lab investigations. Time and temperature are critical issues for specimen collection; this is particularly relevant for viral isolation techniques and for detection of RNA viruses by molecular methods because of RNA degradation.

Diagnostic approaches to viral gastroenteritis include direct methods such as techniques to detect viral infectivity (e.g., viral isolation on cell cultures) and methods to detect virions or their components (e.g., electron microscopy, antigen detection, and nucleic acid detection), as well as indirect methods for the evaluation of virus-specific serological responses. In Table 2, a summary of the main features of diagnostic approaches is reported.

\section{Traditional diagnostic methods}

\section{Electron microscopy (EM)}

Detection of gastroenteritis-producing viruses has traditionally been based on techniques of direct visualization using electron microscopy (EM) [51-53]. Direct EM can be used to screen fecal specimens for enteric viruses in public health laboratories. The turnaround time is rapid (same-day specimen submission and results), and EM has the distinct advantage of uncovering a diagnosis for a wide range of enteric viral pathogens. However, detection of enteric viruses in stool specimens using direct EM requires virus concentrations of at least $10^{6} / \mathrm{mL}$ of stool [54]. Therefore, airfuge techniques or immunoconcentration procedures are required to visualize most of the virions. In many laboratories, stool is mixed with phosphate-buffered saline $(\mathrm{pH} 7.4)$ or tissue culture medium to form a $10 \%$ to $20 \%$ suspension before being clarified by low-speed centrifugation $(4,800 \mathrm{x} \mathrm{g}$ for 15 minutes) to eliminate larger debris. Subsequent concentration of virus may be achieved by ultracentrifugation or precipitation with ammonium sulphate. Virions are negatively stained using phosphotungstic acid, uranyl acetate, or ammonium molybdate [54]. The small numbers of viral particles present in fecal samples make direct EM, even after concentration, relatively insensitive. Moreover, this method requires highly skilled microscopists and expensive equipment, making it not feasible for large epidemiological or clinical survey studies.

Immune EM (IEM) can be used to increase the sensitivity of EM by using specific antibodies or immune sera added to the sample. In this technique, immune sera are used to enhance the detection of the virus by aggregation of viral particles in stool suspensions. The virus clumping that occurs in the presence of specific antibody enables its detection and improves diagnostic capability. IEM has been used to differentiate between the morphologically identical groups $\mathrm{A}, \mathrm{B}$, and $\mathrm{C}$ rotaviruses. However, the technique is useful only for samples collected during the early stages of gastroenteritis, and is laborious, cumbersome, and time-consuming [55]. The lack of detection of viral particles in positive specimens probably reflects the very low concentration of viruses in many stool samples and the lack of first early diarrheal stool samples.

Modifications to the IEM method have been made to improve the detection of viral particles and to simplify the performance of the test. Solid-phase IEM (SPIEM) has been used to capture viral particles directly onto the grid $[54,56,57]$. A SPIEM method

Table 2. Main features of diagnostic approaches to viral gastroenteritis

\begin{tabular}{ccccc}
\hline & Electron microscopy & Viral isolation & Antigen detection & Nucleic acid testing \\
\hline Viruses detected & Wide range & $\begin{array}{c}\text { Wide range } \\
\text { (except caliciviruses) }\end{array}$ & $\begin{array}{c}\text { Very wide range, } \\
\text { Wide range }\end{array}$ & $\begin{array}{c}\text { including identification } \\
\text { of novel pathogens }\end{array}$ \\
\hline Turnaround time & 24 hours & $5-10$ days & 30 min & Low \\
Technical expertise & High & High & Good & High \\
Sensitivity & $\begin{array}{c}\text { Good } \\
\text { at least } 10^{6} / \mathrm{mL} \text { of stool) }\end{array}$ & $\begin{array}{c}\text { Geod } \\
\text { storage important) }\end{array}$ & $\begin{array}{c}\text { (higher in pediatric } \\
\text { patients) }\end{array}$ \\
\hline
\end{tabular}


that uses protein A, goat anti-human immunoglobulin $M(\operatorname{IgM})$, and human serum has been described for serotyping of noroviruses [57].

\section{Immune adherence hemagglutination assay (IAHA)}

The immune adherence hemagglutination assay (IAHA) has been used successfully to detect antibody levels to norovirus in large numbers of sera. In particular, Kapikian et al. used the IAHA to perform epidemiological studies of Norwalk agent seroprevalence in children and adults [58]. Purified viral particles from stool samples are used as an antigen, and antigen-antibody complement interactions are detected in a microtiter plate format by agglutination of sensitive human $\mathrm{O}$ erythrocytes. Comparative studies between the IAHA and the conventional complement-fixation (CF) test revealed that, in most cases, the IAHA was more sensitive than the CF test. Furthermore, diagnosis on the basis of a fourfold change in antibody titer was made more rapidly by the IAHA test. The IAHA test was found to be a very simple and practical technique, requiring only a few hours for completion, compared with the conventional CF test, which required up to 24 hours. Although the IAHA has the advantage of requiring less antigen for its performance than $\mathrm{CF}$, it was soon replaced with another test, the radioimmunoassay (RIA), which uses even less antigen and is more sensitive $[52,59,60]$.

\section{Radioimmunoassay (RIA)}

Radioimmunoassay (RIA) was developed as an alternative method to IEM for the detection of norovirus antigen in stool $[59,60]$. Convalescent sera from a volunteer experimentally infected with norovirus are used to capture virus antigen. Immunoglobulin $\mathrm{G}$ ( $\mathrm{IgG}$ ) purified and radiolabeled with gamma-radioactive isotopes of iodine, such as $125-\mathrm{I}$, is used as a detector system. Although the RIA technique is extremely specific and 10 to 100 times more sensitive than IEM, it requires special precautions since radioactive substances are used [6062]. RIA assays have been modified to detect virusspecific antibodies using a blocking format. Several RIA blocking techniques have been developed for the detection of antibodies to noroviruses; these assays appeared to be 10 to $>200$ times more sensitive than the IAHA [60-62].

\section{Virus isolation}

Cell culture of gastrointestinal viruses is not considered to be useful for diagnostic purposes, as it is technically cumbersome and slow. Among the viruses that have been shown definitively to be causes of gastroenteritis, only caliciviruses cannot be grown in cell culture. The study of rotaviruses, enteric adenoviruses, and astroviruses has been facilitated greatly by the ability to propagate these viruses in cell culture. The ability to cultivate these viruses has allowed the production of reagents for use in diagnostic studies, a better understanding of factors correlated with immunity to infection, and elucidation of each virus's life cycle. In particular, astroviruses were reported to be cultivable in a variety of human and monkey cell lines, although the number of cell lines that are permissive for all eight serotypes is lower [63]. Adenoviruses (subgenera A-E) can be cultured in a variety of cell lines (HeLa, HEp-2, 293, Chang conjunctival, CaCo-2, and PLC/PRF/5 cells), albeit slowly, and thus may be overgrown by other faster-growing viruses [64-68]. Cell-culture isolation of astroviruses and adenoviruses is often combined with immunofluorescence detection by using specific antibodies. However, the maintenance and the use of cell cultures are time consuming and expensive.

\section{Development and application of newer diagnostic tests}

Antigen detection

Recently, a wide variety of tests for the detection of antigen in fecal specimens have been developed. These are based on enzyme immunoassay (EIA), agglutination with latex particles (LA), immunochromatography (IC) and, more recently, chemiluminescent immunoassay (CLIA), all of which are available commercially for human calicivirus, rotavirus, adenovirus, and astrovirus [53,69]. Rapid antigen assays are widely used, as they are able to provide results at the point of care in less than 30 minutes. Moreover, the low cost represents an advantage in the evaluation of the diagnostic work-up. In clinical laboratory practice, rapid and reproducible antigen detection methods seem to be superior among the conventional techniques. The sensitivity of rapid antigen detection is generally higher than that of conventional methods (e.g., EM and IAHA) although lower than that of molecular methods [70-72]. However, these assays are particularly useful in the pediatric setting; the sensitivity is higher in this population because children often shed gastrointestinal viruses at higher titers and for longer time periods than do adults.

Enzyme immunoassay has been proven to be very sensitive and specific for the detection of group A and 
$\mathrm{C}$ rotaviruses in fecal specimens, especially if monoclonal antibodies are used [73,74]. Immunoassay techniques are also available for the detection of astroviruses, due to the development of monoclonal antibodies against these viruses [75-78]. Various formats of astrovirus antigen detection EIAs have been developed for diagnostic purposes. Some of these have been marketed, and have good specificity and sensitivity compared with EM and molecular assays (e.g., IDEIA Astrovirus, Dako Diagnostics, Ltd., Ely, UK, able to detect all eight astrovirus serotypes) $[79,80]$. Several EIA methods using monoclonal and polyclonal antibodies have been developed for the detection of calicivirus. In particular, EIA techniques that use monoclonal antibodies have been evaluated for their ability to detect noroviruses in stool samples. These assays were reported to have a twofold greater sensitivity than assays using polyclonal antibodies [81]. These methods appear promising, although their use currently seems to be limited to research laboratories [51,82]. With respect to adenoviruses, most of these immunoassay techniques detect the common group antigen, and many studies have shown that about $45 \%-95 \%$ of positive specimens for the group antigen correspond to enteric serotypes 40 and 41 [83-86].

The LA technique is used clinically in the identification and typing of most gastrointestinal viruses. Latex particles coated with virus antibodies are agglutinated in the presence of virus antigen to produce the visible aggregates. Although the agglutination test is a more rapid method than EM or EIA, it is relatively less sensitive [53,74].

IC assay is rapid, technically very simple, and showed results comparable to those achieved with EIA $[87,88]$. Given that these tests have a high sensitivity and specificity $(90 \%-95 \%)$, they are widely used in clinical laboratory practice. Most recently, rapid detection strip tests by IC kits have become commercially available for testing for astroviruses and noroviruses in stool specimens (IP Astro V Kit, ImmunoProbe Co. Ltd., Saitama, Japan, and RIDAQUICK Norovirus, R-Biopharm AG, Germany) [89].

The CLIA method is a diagnostic chemiluminescent immunoassay in which the virus antigen is captured by antibodies coupled with a molecule capable of emitting light during a chemical reaction. Light emission is used to measure the formation of the antigen-antibody complex. A CLIA test able to detect rotavirus in stool specimens
(LIAISON Rotavirus, DiaSorin, Saluggia, Italy) has been marketed recently.

\section{Molecular methods}

A wide variety of diagnostic techniques are currently applied for the detection of gastrointestinal viruses. Traditional diagnostic methods such as electron microscopy, serology, and virus isolation have been the mainstay of clinical laboratories, especially in the past two decades. However, these traditional tests lack sensitivity. To overcome the shortcomings of traditional diagnostic methods, molecular techniques have been developed. Several nucleic acid amplification techniques (NAATs), particularly polymerase chain reaction (PCR), realtime PCR, and multiplex PCR, are currently used in routinely in clinical laboratories. Such approaches have allowed rapid diagnosis with a high degree of sensitivity and specificity. Moreover, NAATs have offered additional advantages over traditional methods by production of easily standardized protocols, thus resulting in a potential for automation with a range of options for real-time detection chemistries. The advent of fully automated systems with faster turnaround times has given clinical laboratories the tools necessary to report out accurate and sensitive results to clinicians.

By the end of the decade, a new generation of isothermal amplification techniques will gain wide popularity as diagnostic tools due to their simple operation, rapid reaction, and easy detection. Today, these new techniques, including loop-mediated isothermal amplification (LAMP) and NASBA, are starting to be used routinely in clinical laboratories to detect gastrointestinal viruses. Recently, an astrovirusspecific NASBA assay and a RT-LAMP for the identification of norovirus was developed for rapid detection of vital RNA in large numbers of stool specimens [90].

\section{Conventional molecular methods (end-point PCR, nested PCR)}

PCR has become the method of choice in the epidemiologic survey of gastrointestinal viruses. Currently, PCR is widely employed as a tool for the routine diagnosis of astrovirus, norovirus, sapovirus, rotavirus, and adenovirus infections. These PCR assays are highly sensitive, specific, and easy to perform. The most reliable marker for diagnosis of virus infection is the presence of viral nucleic acid in stool specimens. Therefore, the specimen of choice is stool samples from patients with diarrhea. To facilitate 
the molecular analysis, the amplification of the viral genome and sequencing of the amplification products should be performed, and virus genotypes can be identified based on their sequence analysis. Therefore, PCR assays and nucleic acid sequence analysis are widely used for the detection and genotype identification of viruses causing gastroenteritis [9195]. Gradually, these techniques have replaced the traditional immunological tests and have become the gold standard for diagnosis of gastrointestinal viruses for almost two decades. Nested PCR assays were also developed to increase both sensitivity and specificity. At last, multiplex RT-PCRs have been widely described. In particular, multiplex RT-PCRs for the detection of groups $\mathrm{A}, \mathrm{B}$, and $\mathrm{C}$ rotaviruses and identification of $G$ and $P$ genotypes of group $A$ rotaviruses have been developed.

\section{Real-time PCR}

Real-time PCR technology provides results more quickly than conventional PCR assays and shows improved sensitivity and specificity. Although reagent and instrument costs are higher for real-time PCR technology compared to conventional molecular methods, real-time PCR requires less hands-on time per specimen than traditional PCR, particularly nested PCR, which is labor intensive. Automation of the extraction process and the use of real-time PCR further reduce the hands-on time in the clinical laboratory. Moreover, real-time PCR technology offers advantages over conventional PCR by providing lower risk of false-positive results due to amplicon contamination and quantification of viral load. Realtime PCR assays that detect the most common gastrointestinal viruses in large numbers of stool specimens have been developed [96-105].

\section{Conclusions}

Viral gastroenteritis is second only to viral respiratory diseases as a cause of morbidity and mortality worldwide, with most cases occurring in young children in non-industrialized countries.

Diagnosis of viral gastroenteritis was previously based on conventional methods such as electron microscopy or indirect methods for the evaluation of virus-specific serological response. However, even when these methods were combined, some clinical specimens resulted negative despite clinical or epidemiological evidence of gastrointestinal infection. In this context, antigen detection and especially molecular approaches have greatly improved the ability of the clinical laboratory to diagnose viral gastroenteritis. NAATs have been shown to be more specific and sensitive compared to non-nucleic-acidbased methods. Thus, infected patients will be diagnosed more accurately and much more quickly during the course of viral infection when they are shedding low levels of virus, by using NAATs rather than non-molecular tests. Moreover, an accurate diagnosis provides more accurate information to public health authorities regarding the epidemiology of viruses causing gastroenteritis.

\section{Acknowledgements}

This paper is dedicated to Prof. Piero Cappuccinelli.

Francesca Sidoti acknowledges a research grant by Fondazione Carlo Denegri Onlus Turin, Italy;

Massimo Rittà acknowledges a grant for the Lagrange Project - CRT Foundation/ISI Foundation, Italy.

\section{References}

1. Ramani S, Kang G (2009) Viruses causing childhood diarrhoea in the developing world. Curr Opin Infect Dis 22: 477-482.

2. Scallan E, Griffin PM, Angulo FJ, Tauxe RV, Hoekstra RM (2011) Foodborne illness acquired in the United States-unspecified agents. Emerg Infect Dis 17: 16-22.

3. Murray CJ, Vos T, Lozano R, Naghavi M, Flaxman AD, Michaud C, Ezzati M, Shibuya K, Salomon JA, Abdalla S, Aboyans V, Abraham J, Ackerman I, Aggarwal R, Ahn SY, Ali MK, Alvarado M, Anderson HR, Anderson LM, Andrews KG, Atkinson C, Baddour LM, Bahalim AN, Barker-Collo S, Barrero LH, Bartels DH, Basáñez MG, Baxter A, Bell ML, Benjamin EJ, Bennett D, Bernabé E, Bhalla K, Bhandari B, Bikbov B, Bin Abdulhak A, Birbeck G, Black JA, Blencowe H, Blore JD, Blyth F, Bolliger I, Bonaventure A, Boufous S, Bourne R, Boussinesq M, Braithwaite T, Brayne C, Bridgett L, Brooker S, Brooks P, Brugha TS, Bryan-Hancock C, Bucello C, Buchbinder R, Buckle G, Budke CM, Burch M, Burney P, Burstein R, Calabria B, Campbell B, Canter CE, Carabin H, Carapetis J, Carmona L, Cella C, Charlson F, Chen H, Cheng AT, Chou D, Chugh SS, Coffeng LE, Colan $\mathrm{SD}$, Colquhoun S, Colson KE, Condon J, Connor MD, Cooper LT, Corriere M, Cortinovis M, de Vaccaro KC, Couser W, Cowie BC, Criqui MH, Cross M, Dabhadkar KC, Dahiya M, Dahodwala N, Damsere-Derry J, Danaei G, Davis A, De Leo D, Degenhardt L, Dellavalle R, Delossantos A, Denenberg J, Derrett S, Des Jarlais DC, Dharmaratne SD, Dherani M, Diaz-Torne C, Dolk H, Dorsey ER, Driscoll T, Duber H, Ebel B, Edmond K, Elbaz A, Ali SE, Erskine H, Erwin PJ, Espindola P, Ewoigbokhan SE, Farzadfar F, Feigin V, Felson DT, Ferrari A, Ferri CP, Fèvre EM, Finucane MM, Flaxman S, Flood L, Foreman K, Forouzanfar MH, Fowkes FG, Fransen M, Freeman MK, Gabbe BJ, Gabriel SE, Gakidou E, Ganatra HA, Garcia B, Gaspari F, Gillum RF, Gmel G, Gonzalez-Medina D, Gosselin R, Grainger R, Grant B, Groeger J, Guillemin F, Gunnell D, Gupta R, Haagsma J, Hagan H, Halasa YA, Hall W, Haring D, Haro JM, Harrison JE, Havmoeller R, Hay RJ, Higashi H, Hill C, Hoen B, Hoffman H, Hotez PJ, Hoy D, Huang JJ, Ibeanusi SE, 
Jacobsen KH, James SL, Jarvis D, Jasrasaria R, Jayaraman S, Johns N, Jonas JB, Karthikeyan G, Kassebaum N, Kawakami N, Keren A, Khoo JP, King CH, Knowlton LM, Kobusingye O, Koranteng A, Krishnamurthi R, Laden F, Lalloo R, Laslett LL, Lathlean T, Leasher JL, Lee YY, Leigh J, Levinson D, Lim SS, Limb E, Lin JK, Lipnick M, Lipshultz SE, Liu W, Loane M, Ohno SL, Lyons R, Mabweijano J, MacIntyre MF, Malekzadeh R, Mallinger L, Manivannan S, Marcenes W, March L, Margolis DJ, Marks GB, Marks R, Matsumori A, Matzopoulos R, Mayosi BM, McAnulty JH, McDermott MM, McGill N, McGrath J, Medina-Mora ME, Meltzer M, Mensah GA, Merriman TR, Meyer AC, Miglioli V, Miller M, Miller TR, Mitchell PB, Mock C, Mocumbi AO, Moffitt TE, Mokdad AA, Monasta L, Montico M, Moradi-Lakeh M, Moran A, Morawska L, Mori R, Murdoch ME, Mwaniki MK, Naidoo K, Nair MN, Naldi L, Narayan KM, Nelson PK, Nelson RG, Nevitt MC, Newton CR, Nolte S, Norman P, Norman R, O'Donnell M, O'Hanlon S, Olives C, Omer SB, Ortblad K, Osborne R, Ozgediz D, Page A, Pahari B, Pandian JD, Rivero AP, Patten SB, Pearce N, Padilla RP, Perez-Ruiz F, Perico N, Pesudovs K, Phillips D, Phillips MR, Pierce K, Pion S, Polanczyk GV, Polinder S, Pope CA 3rd, Popova S, Porrini E, Pourmalek F, Prince M, Pullan RL, Ramaiah KD, Ranganathan D, Razavi H, Regan M, Rehm JT, Rein DB, Remuzzi G, Richardson K, Rivara FP, Roberts T, Robinson C, De Leòn FR, Ronfani L, Room R, Rosenfeld LC, Rushton L, Sacco RL, Saha S, Sampson U, Sanchez-Riera L, Sanman E, Schwebel DC, Scott JG, Segui-Gomez M, Shahraz S, Shepard DS, Shin H, Shivakoti R, Singh D, Singh GM, Singh JA, Singleton J, Sleet DA, Sliwa K, Smith E, Smith JL, Stapelberg NJ, Steer A, Steiner T, Stolk WA, Stovner LJ, Sudfeld C, Syed S, Tamburlini G, Tavakkoli M, Taylor HR, Taylor JA, Taylor WJ, Thomas B, Thomson WM, Thurston GD, Tleyjeh IM, Tonelli M, Towbin JA, Truelsen T, Tsilimbaris MK, Ubeda C, Undurraga EA, van der Werf MJ, van Os J, Vavilala MS, Venketasubramanian N, Wang M, Wang W, Watt K, Weatherall DJ, Weinstock MA, Weintraub R, Weisskopf MG, Weissman MM, White RA, Whiteford H, Wiebe N, Wiersma ST, Wilkinson JD, Williams HC, Williams SR, Witt E, Wolfe F, Woolf AD, Wulf S, Yeh PH, Zaidi AK, Zheng ZJ, Zonies D, Lopez AD, AlMazroa MA, Memish ZA (2012) Disability-adjusted life years (DALYs) for 291 diseases and injuries in 21 regions, 1990-2010: a systematic analysis for the Global Burden of Disease Study 2010. Lancet 380: 2197-2223.

4. Lozano R, Naghavi M, Foreman K, Lim S, Shibuya K, Aboyans V, Abraham J, Adair T, Aggarwal R, Ahn SY, Alvarado M, Anderson HR, Anderson LM, Andrews KG, Atkinson C, Baddour LM, Barker-Collo S, Bartels DH, Bell ML, Benjamin EJ, Bennett D, Bhalla K, Bikbov B, Bin Abdulhak A, Birbeck G, Blyth F, Bolliger I, Boufous S, Bucello C, Burch M, Burney P, Carapetis J, Chen H, Chou D, Chugh SS, Coffeng LE, Colan SD, Colquhoun S, Colson KE, Condon J, Connor MD, Cooper LT, Corriere M, Cortinovis M, de Vaccaro KC, Couser W, Cowie BC, Criqui MH, Cross M, Dabhadkar KC, Dahodwala N, De Leo D, Degenhardt L, Delossantos A, Denenberg J, Des Jarlais DC, Dharmaratne SD, Dorsey ER, Driscoll T, Duber H, Ebel B, Erwin PJ, Espindola P, Ezzati M, Feigin V, Flaxman AD, Forouzanfar MH, Fowkes FG, Franklin R, Fransen M, Freeman MK, Gabriel SE, Gakidou E, Gaspari F, Gillum RF, GonzalezMedina D, Halasa YA, Haring D, Harrison JE, Havmoeller R, Hay RJ, Hoen B, Hotez PJ, Hoy D, Jacobsen KH, James SL,
Jasrasaria R, Jayaraman S, Johns N, Karthikeyan G, Kassebaum N, Keren A, Khoo JP, Knowlton LM, Kobusingye O, Koranteng A, Krishnamurthi R, Lipnick M, Lipshultz SE, Ohno SL, Mabweijano J, MacIntyre MF, Mallinger L, March L, Marks GB, Marks R, Matsumori A, Matzopoulos R, Mayosi BM, McAnulty JH, McDermott MM, McGrath J, Mensah GA, Merriman TR, Michaud C, Miller M, Miller TR, Mock C, Mocumbi AO, Mokdad AA, Moran A, Mulholland K, Nair MN, Naldi L, Narayan KM, Nasseri K, Norman P, O'Donnell M, Omer SB, Ortblad K, Osborne R, Ozgediz D, Pahari B, Pandian JD, Rivero AP, Padilla RP, Perez-Ruiz F, Perico N, Phillips D, Pierce K, Pope CA III, Porrini E, Pourmalek F, Raju M, Ranganathan D, Rehm JT, Rein DB, Remuzzi G, Rivara FP, Roberts T, De León FR, Rosenfeld LC, Rushton L, Sacco RL, Salomon JA, Sampson U, Sanman E, Schwebel DC, Segui-Gomez M, Shepard DS, Singh D, Singleton J, Sliwa K, Smith E, Steer A, Taylor JA, Thomas B, Tleyjeh IM, Towbin JA, Truelsen T, Undurraga EA, Venketasubramanian N, Vijayakumar L, Vos T, Wagner GR, Wang M, Wang W, Watt K, Weinstock MA, Weintraub R, Wilkinson JD, Woolf AD, Wulf S, Yeh PH, Yip P, Zabetian A, Zheng ZJ, Lopez AD, Murray CJ, AlMazroa MA, Memish ZA 2012. Global and regional mortality from 235 causes of death for 20 age groups in 1990 and 2010: a systematic analysis for the Global Burden of Disease Study 2010. Lancet 380: 2095-2128.

5. GBD 2013 Mortality and Causes of Death Collaborators (2015) Global, regional, and national age-sex specific allcause and cause-specific mortality for 240 causes of death, 1990-2013: a systematic analysis for the Global Burden of Disease Study 2013. Lancet 385: 117-171.

6. Liu L, Johnson HL, Cousens S, Perin J, Scott S, Lawn JE, Rudan I, Campbell H, Cibulskis R, Li M, Mathers C, Black RE (2012) Global, regional, and national causes of child mortality: an updated systematic analysis for 2010 with time trends since 2000. Lancet 379: 2151-2161.

7. Chhabra P, Payne DC, Szilagyi PG, Edwards KM, Staat MA, Shirley SH, Wikswo M, Nix WA, Lu X, Parashar UD, Vinje J (2013) Etiology of viral gastroenteritis in children <5 years of age in the United States, 2008-2009. J Infect Dis 208: 790800.

8. Hall AJ, Wikswo ME, Manikonda K, Roberts VA, Yoder JS, Gould LH (2013) Acute gastroenteritis surveillance through the National Outbreak Reporting System, United States. Emerg Infect Dis 19: 1305-1309.

9. Walker CL, Aryee MJ, Boschi-Pinto C, Black RE (2012) Estimating diarrhea mortality among young children in low and middle income countries. PLoS One 7: e29151.

10. Ahmed SM, Hall AJ, Robinson AE, Verhoef L, Premkumar P, Parashar UD, Koopmans M, Lopman BA (2014) Global prevalence of norovirus in cases of gastroenteritis: a systematic review and meta-analysis. Lancet Infect Dis 14: 725-730.

11. Verma H, Chitambar SD, Gopalkrishna V (2011) Circulation of Aichi virus genotype B strains in children with acute gastroenteritis in India. Epidemiol Infect 139: 1687-1691.

12. Benschop K, Thomas X, Serpenti C, Molenkamp R, Wolthers K (2008) High prevalence of human Parechovirus (HPeV) genotypes in the Amsterdam region and identification of specific HPeV variants by direct genotyping of stool samples. J Clin Microbiol 46: 3965-3970.

13. Cheng WX, Jin Y, Duan ZJ, Xu ZQ, Qi HM, Zhang Q, Yu JM, Zhu L, Jin M, Liu N, Cui SX, Li HY, Fang ZY (2008) 
Human bocavirus in children hospitalized for acute gastroenteritis: a case-control study. Clin Infect Dis 47: 161167.

14. Zhang DL, Jin Y, Li DD, Cheng WX, Xu ZQ, Yu JM, Jin M, Yang SH, Zhang Q, Cui SX, Liu N, Duan ZJ (2011) Prevalence of human parechovirus in Chinese children hospitalized for acute gastroenteritis. Clin Microbiol Infect 17: 1563-1569.

15. Payne DC, Vinje J, Szilagyi PG, Edwards KM, Staat MA, Weinberg GA, Hall CB, Chappell J, Bernstein DI, Curns AT, Wikswo M, Shirley SH, Hall AJ, Lopman B, Parashar UD (2013) Norovirus and medically attended gastroenteritis in U.S. children. N Engl J Med 368: 1121-1130.

16. Khamrin P, Ushijima H, Maneekarn N (2011) Norovirus. In Liu D, editor. Molecular detection of human viral pathogens. Florida: CRC Press. 111-117.

17. Turcios RM, Widdowson MA, Sulka AC, Mead PS, Glass RI (2006) Reevaluation of epidemiological criteria for identifying outbreaks of acute gastroenteritis due to norovirus: United States, 1998-2000. Clin Infect Dis 42: 964-969.

18. Smith MJ, Clark HF, Lawley D, Bell LM, Hodinka RL, DiStefano DJ, Kulnis G, Zaoutis TE, Coffin SE (2008) The clinical and molecular epidemiology of community- and healthcare-acquired rotavirus gastroenteritis. Pediatr Infect Dis J 27: 54-58.

19. Ospino DU, Young G, Navarro OA (2008) Viral gastroenteritis and diversity of Rotavirus strains in Colombian children: a systematic review. J Infect Dev Ctries 2: 99-105. doi:10.3855/jidc. 278 .

20. Ramani S, Atmar RL, Estes MK (2014) Epidemiology of human noroviruses and updates on vaccine development. Curr Opin Gastroenterol 30: 25-33.

21. Matthews JE, Dickey BW, Miller RD, Felzer JR, Dawson BP, Lee AS, Rocks JJ, Kiel J, Montes JS, Moe CL, Eisenberg JN, Leon JS (2012) The epidemiology of published norovirus outbreaks: a review of risk factors associated with attack rate and genogroup. Epidemiol Infect 140: 1161-1172.

22. Bok K, Green KY (2012) Norovirus gastroenteritis in immunocompromised patients. N Engl J Med 367: 21262132.

23. Caul EO (1994) Small round structured viruses: airborne transmission and hospital control. Lancet 343: 1240-1242.

24. Thornton AC, Jennings-Conklin KS, McCormick MI (2004) Noroviruses: agents in outbreaks of acute gastroenteritis. Disaster Manag Response 2: 4-9.

25. Tan M, Jiang X (2014) Histo-blood group antigens: a common niche for norovirus and rotavirus. Expert Rev Mol Med 16: e5.

26. Madeley CR, Cosgrove BP (1976) Letter: Caliciviruses in man. Lancet 1: 199-200.

27. Chiba S, Sakuma Y, Kogasaka R, Akihara M, Horino K, Nakao T, Fukui S (1979) An outbreak of gastroenteritis associated with calicivirus in an infant home. J Med Virol 4: 249-254.

28. Oka T, Wang Q, Katayama K, Saif LJ (2015) Comprehensive review of human sapoviruses. Clin Microbiol Rev 28: 32-53.

29. Hansman GS, Saito H, Shibata C, Ishizuka S, Oseto M, Oka T, Takeda N (2007) Outbreak of gastroenteritis due to sapovirus. J Clin Microbiol 45: 1347-1349.

30. Hansman GS (2011) Sapoviruses. In Liu D, Editor. Molecular detection of human viral pathogens. Florida: CRC Press. 119127.
31. Frange P, Touzot F, Debre M, Heritier S, Leruez-Ville M, Cros G, Rouzioux C, Blanche S, Fischer A, Avettand-Fenoel V (2012) Prevalence and clinical impact of norovirus fecal shedding in children with inherited immune deficiencies. J Infect Dis 206: 1269-1274.

32. Cubitt WD, McSwiggan DA (1987) Seroepidemiological survey of the prevalence of antibodies to a strain of human calicivirus. J Med Virol 21: 361-368.

33. Nakata S, Estes MK, Chiba S (1988) Detection of human calicivirus antigen and antibody by enzyme-linked immunosorbent assays. J Clin Microbiol 26: 2001-2005.

34. Sakuma Y, Chiba S, Kogasaka R, Terashima H, Nakamura S, Horino K, Nakao T (1981) Prevalence of antibody to human calicivirus in general population of northern Japan. J Med Virol 7: 221-225.

35. Nakata S, Chiba S, Terashima H, Nakao T (1985) Prevalence of antibody to human calicivirus in Japan and Southeast Asia determined by radioimmunoassay. J Clin Microbiol 22: 519521.

36. Wadell G (1984) Molecular epidemiology of human adenoviruses. Curr Top Microbiol Immunol 110: 191-220.

37. Scott-Taylor TH, Hammond GW (1995) Local succession of adenovirus strains in pediatric gastroenteritis. J Med Virol 45: 331-338.

38. Gerba CP, Rodrìguez RA (2011) Adenoviruses. In Liu D, editor. Molecular detection of human viral pathogens. Florida: CRC Press. 893-899.

39. Walter JE, Mitchell DK (2003) Astrovirus infection in children. Curr Opin Infect Dis 16: 247-253.

40. Mendez-Toss M, Griffin DD, Calva J, Contreras JF, Puerto FI, Mota F, Guiscafre H, Cedillo R, Munoz O, Herrera I, Lopez S, Arias CF (2004) Prevalence and genetic diversity of human astroviruses in Mexican children with symptomatic and asymptomatic infections. J Clin Microbiol 42: 151-157.

41. Herrmann JE, Taylor DN, Echeverria P, Blacklow NR (1991) Astroviruses as a cause of gastroenteritis in children. N Engl J Med 324: 1757-1760.

42. Nazer H, Rice S, Walker-Smith JA (1982) Clinical associations of stool astrovirus in childhood. J Pediatr Gastroenterol Nutr 1: 555-558.

43. Mansour AM, El Koutby M, El Barbary MM, Mohamed W, Shehata S, El Mohammady H, Mostafa M, Riddle MS, Sebeny PJ, Young SY, Abdel-Messih I (2013) Enteric viral infections as potential risk factors for intussusception. J Infect Dev Ctries 7: 28-35. doi:10.3855/jidc.2321.

44. Meleg E, Bányai K (2011) Astroviruses. In Liu D, editor. Molecular detection of human viral pathogens. Florida: CRC Press. 89-98.

45. Tate JE, Burton AH, Boschi-Pinto C, Steele AD, Duque J, Parashar UD, WHO-coordinated Global Rotavirus Surveillance Network (2012) 2008 estimate of worldwide rotavirus-associated mortality in children younger than 5 years before the introduction of universal rotavirus vaccination programmes: a systematic review and metaanalysis. Lancet Infect Dis 12: 136-141.

46. Lanata CF, Fischer-Walker CL, Olascoaga AC, Torres CX, Aryee MJ, Black RE, Child Health Epidemiology Reference Group of the World Health Organization and UNICEF (2013) Global causes of diarrheal disease mortality in children $<5$ years of age: a systematic review. PLoS One 8: e72788.

47. Dickey M, Jamison L, Michaud L, Care M, Bernstein DI, Staat MA (2009) Rotavirus meningoencephalitis in a 
previously healthy child and a review of the literature. Pediatr Infect Dis J 28: 318-321.

48. Parashar UD, Nelson EA, Kang G (2013) Diagnosis, management, and prevention of rotavirus gastroenteritis in children. BMJ 347: f7204.

49. Estes MK, Kapikian AZ (2007) Rotaviruses. In Knipe D, Griffin D, Lamb R, Martin M, Roizman B, Straus S, editors. Fields Virology. Lippincott, Williams and Wilkins, Philadelphia, PA. 1917-1975.

50. Desselberger U (2014) Rotaviruses. Virus Res 190: 75-96.

51. Atmar RL, Estes MK (2001) Diagnosis of noncultivatable gastroenteritis viruses, the human caliciviruses. Clin Microbiol Rev 14: 15-37.

52. Kapikian AZ, Chanock RM (1996) Rotaviruses. In Fields BN, Knipe DM, Howley PM, editors.Virology, $3^{\text {rd }}$ edition. Philadelphia: Lippincott-Raven Press. 1657-1708.

53. Christensen ML (1999) Rotaviruses. In Murray PR, Baron EJ, Pfaller MA, Tenover FC, Yolken RH, editors. Manual of Clinical Microbiology. Washington: ASM Press. 999-1004.

54. Doane FW (1994) Electron microscopy for the detection of gastroenteritis viruses. In Kapikian AZ, editor. Viral Infections of the Gastrointestinal Tract. New York: Marcel Dekker. 101-130.

55. Lewis DC (1990) Three serotypes of Norwalk-like virus demonstrated by solid-phase immune electron microscopy. J Med Virol 30: 77-81.

56. Lewis D (1991) Norwalk agent and other small-round structured viruses in the U.K. J Infect 23: 220-222.

57. Lewis DC, Lightfoot NF, Pether JV (1988) Solid-phase immune electron microscopy with human immunoglobulin $\mathrm{M}$ for serotyping of Norwalk-like viruses. J Clin Microbiol 26: 938-942.

58. Kapikian AZ, Greenberg HB, Cline WL, Kalica AR, Wyatt RG, James HD Jr., Lloyd NL, Chanock RM, Ryder RW, Kim HW (1978) Prevalence of antibody to the Norwalk agent by a newly developed immune adherence hemagglutination assay. J Med Virol 2: 281-294.

59. Greenberg HB, Kapikian AZ (1978) Detection of Norwalk agent antibody and antigen by solid-phase radioimmunoassay and immune adherence hemagglutination assay. J Am Vet Med Assoc 173: 620-623.

60. Greenberg HB, Wyatt RG, Valdesuso J, Kalica AR, London WT, Chanock RM, Kapikian AZ (1978) Solid-phase microtitre radioimmunoassay for detection of the Norwalk strain of acute nonbacterial, epidemic gastroenteritis virus and its antibodies. J Med Virol 2: 97-108.

61. Dolin R, Roessner KD, Treanor JJ, Reichman RC, Phillips M, Madore HP (1986) Radioimmunoassay for detection of the Snow Mountain Agent of viral gastroenteritis. J Med Virol 19: 11-18.

62. Nakata S, Chiba S, Terashima H, Sakuma Y, Kogasaka R, Nakao T (1983) Microtiter solid-phase radioimmunoassay for detection of human calicivirus in stools. J Clin Microbiol 17: 198-201.

63. Matsui SM (2002) Astrovirus. In Richman DD, Whitley RJ, Hayden FG, editors. Clinical Virology. Washington: ASM Press. 1075-1086.

64. Irving LG, Smith FA (1981) One-year survey of enteroviruses, adenoviruses, and reoviruses isolated from effluent at an activated-sludge purification plant. Appl Environ Microbiol 41: 51-59.
65. Brown M (1990) Laboratory identification of adenoviruses associated with gastroenteritis in Canada from 1983 to 1986. J Clin Microbiol 28: 1525-1529.

66. Grabow WO, Puttergill DL, Bosch A (1992) Propagation of adenovirus types 40 and 41 in the PLC/PRF/5 primary liver carcinoma cell line. J Virol Methods 37: 201-207.

67. Tani N, Dohi Y, Kurumatani N, Yonemasu K (1995) Seasonal distribution of adenoviruses, enteroviruses and reoviruses in urban river water. Microbiol Immunol 39: 577 580.

68. Echavarria M, Forman M, Ticehurst J, Dumler JS, Charache P (1998) PCR method for detection of adenovirus in urine of healthy and human immunodeficiency virus-infected individuals. J Clin Microbiol 36: 3323-3326.

69. Petric M (1999) Caliciviruses, astroviruses and other diarrheic viruses. In Murray PR, Baron EJ, Pfaller MA, Tenover FC, Yolken RH, editors. Manual of Clinical Microbiology. Washington: ASM Press. 1005-1013.

70. Bereciartu A, Bok K, Gomez J (2002) Identification of viral agents causing gastroenteritis among children in Buenos Aires, Argentina. J Clin Virol 25: 197-203.

71. Dalton RM, Roman ER, Negredo AA, Wilhelmi ID, Glass RI, Sanchez-Fauquier A (2002) Astrovirus acute gastroenteritis among children in Madrid, Spain. Pediatr Infect Dis J 21: 1038-1041.

72. Marie-Cardine A, Gourlain K, Mouterde O, Castignolles N, Hellot MF, Mallet E, Buffet-Janvresse C (2002) Epidemiology of acute viral gastroenteritis in children hospitalized in Rouen, France. Clin Infect Dis 34: 1170-1178.

73. Dennehy PH, Gauntlett DR, Tente WE (1988) Comparison of nine commercial immunoassays for the detection of rotavirus in fecal specimens. J Clin Microbiol 26: 1630-1634.

74. Thomas EE, Puterman ML, Kawano E, Curran M (1988) Evaluation of seven immunoassays for detection of rotavirus in pediatric stool samples. J Clin Microbiol 26: 1189-1193.

75. Bass DM, Upadhyayula U (1997) Characterization of human serotype 1 astrovirus-neutralizing epitopes. J Virol 71: 86668671.

76. Herrmann JE, Nowak NA, Perron-Henry DM, Hudson RW, Cubitt WD, Blacklow NR (1990) Diagnosis of astrovirus gastroenteritis by antigen detection with monoclonal antibodies. J Infect Dis 161: 226-229.

77. Shastri S, Doane AM, Gonzales J, Upadhyayula U, Bass DM (1998) Prevalence of astroviruses in a children's hospital. J Clin Microbiol 36: 2571-2574.

78. Moe CL, Allen JR, Monroe SS, Gary HE, Jr., Humphrey CD, Herrmann JE, Blacklow NR, Carcamo C, Koch M, Kim KH, Glass RI (1991) Detection of astrovirus in pediatric stool samples by immunoassay and RNA probe. J Clin Microbiol 29: 2390-2395.

79. McIver CJ, Palombo EA, Doultree JC, Mustafa H, Marshall JA, Rawlinson WD (2000) Detection of astrovirus gastroenteritis in children. J Virol Methods 84: 99-105.

80. Putzker M, Sauer H, Kirchner G, Keksel O, Malic A (2000) Community acquired diarrhea--the incidence of Astrovirus infections in Germany. Clin Lab 46: 269-273.

81. Herrmann JE, Blacklow NR, Matsui SM, Lewis TL, Estes MK, Ball JM, Brinker JP (1995) Monoclonal antibodies for detection of Norwalk virus antigen in stools. J Clin Microbiol 33: 2511-2513.

82. Jiang X, Wilton N, Zhong WM, Farkas T, Huang PW, Barrett E, Guerrero M, Ruiz-Palacios G, Green KY, Green J, Hale AD, Estes MK, Pickering LK, Matson DO (2000) Diagnosis 
of human caliciviruses by use of enzyme immunoassays. J Infect Dis 181 Suppl 2: S349-S359.

83. Grimwood K, Carzino R, Barnes GL, Bishop RF (1995) Patients with enteric adenovirus gastroenteritis admitted to an Australian pediatric teaching hospital from 1981 to 1992 . J Clin Microbiol 33: 131-136.

84. Kotloff KL, Losonsky GA, Morris JG, Jr., Wasserman SS, Singh-Naz N, Levine MM (1989) Enteric adenovirus infection and childhood diarrhea: an epidemiologic study in three clinical settings. Pediatrics 84: 219-225.

85. Moore PL, Steele AD, Alexander JJ (2000) Relevance of commercial diagnostic tests to detection of enteric adenovirus infections in South Africa. J Clin Microbiol 38: 1661-1663.

86. Noel J, Mansoor A, Thaker U, Herrmann J, Perron-Henry D, Cubitt WD (1994) Identification of adenoviruses in faeces from patients with diarrhoea at the Hospitals for Sick Children, London, 1989-1992. J Med Virol 43: 84-90.

87. Dennehy PH, Hartin M, Nelson SM, Reising SF (1999) Evaluation of the ImmunoCardSTAT! rotavirus assay for detection of group A rotavirus in fecal specimens. J Clin Microbiol 37: 1977-1979.

88. Wilhelmi I, Colomina J, Martin-Rodrigo D, Roman E, Sanchez-Fauquier A (2001) New immunochromatographic method for rapid detection of rotaviruses in stool samples compared with standard enzyme immunoassay and latex agglutination techniques. Eur J Clin Microbiol Infect Dis 20: 741-743.

89. Khamrin P, Dey SK, Chan-it W, Thongprachum A, Satou K, Okitsu S, Maneekarn N, Ushijima H (2010) Evaluation of a rapid immunochromatography strip test for detection of astrovirus in stool specimens. J Trop Pediatr 56: 129-131.

90. Tai JH, Ewert MS, Belliot G, Glass RI, Monroe SS (2003) Development of a rapid method using nucleic acid sequencebased amplification for the detection of astrovirus. J Virol Methods 110: 119-127.

91. Gouvea V, Santos N (1999) Rotavirus serotype G5: an emerging cause of epidemic childhood diarrhea. Vaccine 17: 1291-1292.

92. Lee TW, Kurtz JB (1994) Prevalence of human astrovirus serotypes in the Oxford region 1976-92, with evidence for two new serotypes. Epidemiol Infect 112: 187-193.

93. Noel JS, Lee TW, Kurtz JB, Glass RI, Monroe SS (1995) Typing of human astroviruses from clinical isolates by enzyme immunoassay and nucleotide sequencing. J Clin Microbiol 33: 797-801.

94. Gouvea V, Glass RI, Woods P, Taniguchi K, Clark HF, Forrester B, Fang ZY (1990) Polymerase chain reaction amplification and typing of rotavirus nucleic acid from stool specimens. J Clin Microbiol 28: 276-282.

95. Gentsch JR, Glass RI, Woods P, Gouvea V, Gorziglia M, Flores J, Das BK, Bhan MK (1992) Identification of group A rotavirus gene 4 types by polymerase chain reaction. J Clin Microbiol 30: 1365-1373.

96. Zhang Z, Mitchell DK, Afflerbach C, Jakab F, Walter J, Zhang YJ, Staat MA, Azimi P, Matson DO (2006) Quantitation of human astrovirus by real-time reverse- transcription-polymerase chain reaction to examine correlation with clinical illness. J Virol Methods 134: 190196.

97. Royuela E, Negredo A, Sanchez-Fauquier A (2006) Development of a one step real-time RT-PCR method for sensitive detection of human astrovirus. J Virol Methods 133: 14-19.

98. Logan C, O'Leary JJ, O'Sullivan N (2007) Real-time reverse transcription PCR detection of norovirus, sapovirus and astrovirus as causative agents of acute viral gastroenteritis. J Virol Methods 146: 36-44.

99. Le Cann P, Ranarijaona S, Monpoeho S, Le Guyader F, Ferre V (2004) Quantification of human astroviruses in sewage using real-time RT-PCR. Res Microbiol 155: 11-15.

100. Kageyama T, Kojima S, Shinohara M, Uchida K, Fukushi S, Hoshino FB, Takeda N, Katayama K (2003) Broadly reactive and highly sensitive assay for Norwalk-like viruses based on real-time quantitative reverse transcription-PCR. J Clin Microbiol 41: 1548-1557.

101. Oka T, Katayama K, Hansman GS, Kageyama T, Ogawa S, Wu FT, White PA, Takeda N (2006) Detection of human sapovirus by real-time reverse transcription-polymerase chain reaction. J Med Virol 78: 1347-1353.

102. Gunson RN, Collins TC, Carman WF (2006) The real-time detection of sapovirus. J Clin Virol 35: 321-322.

103. Chan MC, Sung JJ, Lam RK, Chan PK, Lai RW, Leung WK (2006) Sapovirus detection by quantitative real-time RT-PCR in clinical stool specimens. J Virol Methods 134: 146-153.

104. Gutierrez-Aguirre I, Steyer A, Boben J, Gruden K, PoljsakPrijatelj M, Ravnikar M (2008) Sensitive detection of multiple rotavirus genotypes with a single reverse transcription-real-time quantitative PCR assay. J Clin Microbiol 46: 2547-2554.

105. Freeman MM, Kerin T, Hull J, McCaustland K, Gentsch J (2008) Enhancement of detection and quantification of rotavirus in stool using a modified real-time RT-PCR assay. J Med Virol 80: 1489-1496.

106. Scheuer KA, Oka T, Hoet AE, Gebreyes WA, Molla BZ, Saif LJ, Wang Q (2013) Prevalence of porcine noroviruses, molecular characterization of emerging porcine sapoviruses from finisher swine in the United States, and unified classification scheme for sapoviruses. J Clin Microbiol 51: 2344-2353.

\section{Corresponding author}

Dr. Francesca Sidoti

Microbiology and Virology Unit, Laboratory of Virology

University Hospital Città della Salute e della Scienza di Torino

Via Santena 9, 10126

Turin, Italy

Phone: +390116705640

Fax: +390116705648

Email: francesca.sidoti@unito.it

Conflict of interests: No conflict of interests is declared. 